Стаття надійшла до редакиї 31.05.2021 p.

Перевірено на плагіат 07.06.2021 p.

унікальність $-98.12 \%$

https://doi.org/10.17721/StudLing2021.19.166-175

УДК 81'2/'44:316.286

\title{
SPEECH ACT OF REFUSAL IN CHINESE AND JAPANESE LINGUAL CULTURES: CONTEMPORARY THEORETICAL APPROACHES
}

\author{
Jiang Qingchuan, qingchuanjiang6@gmail.com \\ PhD student of Educational and Scientific Institute of Philology \\ Taras Shevchenko National University of Kyiv
}

Refusal, as a speech act that can easily threaten both sides of communication, is a problem that needs to be handled with special care in cross-cultural communication. If the refusal is not handled properly, not only the communication might fail to proceed smoothly, but it even can destroy the relationship between the two parties and cause adverse consequences. Therefore, the implementation of the speech act of refusal requires certain strategies. Due to the differences between different languages, cultures, living habits and ways of thinking, there will be differences in the way of refusal between Chinese and Japanese. In order to reduce the negative impact of cultural differences and other factors of cross-cultural communication between Chinese and Japanese, as well as promoting smoother cross-cultural interaction, the Chinese-Japanese refusal speech act should be thoroughly analyzed in both theoretical and practical aspects. For the time being there are already tangible results in the comparative theoretical research of speech refusal act in the Chinese and Japanese lingual cultures. This article aims to summarize and review the previous researches, as well as to seek inspiration for exploring the new directions and the new entry points in this research field in order to facilitate the future innovative research.

Key words: refusal speech act, cross-cultural communication, cultural differences, refusal strategy, comparative study.

(C) Jiang Qingchuan [Czjan Cinchuan'], qingchuanjiang6@gmail.com Speech Act of Refusal in Chinese and Japanese Lingual Cultures: Contemporary Theoretical Approaches

[Movlennjevyj akt vidmovy v kytajs'kij ta japons'kij lingvokul'turah: suchasni teoretychni pidhody] 


\title{
МОВЛЕННСВИЙ АКТ ВІДМОВИ В КИТАЙСЬКІЙ ТА ЯПОНСЬКІЙ ЛІНГВОКУЛЬТУРАХ: СУЧАСНІ ТЕОРЕТИЧНІ ПІДХОДИ
}

\author{
Цзян Цінчуань, qingchuanjiang6@gmail.com
}

\author{
аспірантка Навчально-наукового інституту філології \\ Київький національний університет імені Тараса Шевченка
}

Відмова як мовленнєвий акт, котрий може загрожувати обом сторонам спілкування під час міжкультурної комунікащї є проблемою, яка потребує особливої уваги. Якщо відмова буде здійснена некорректно, це може не тільки зашкодити спілкуванню, а й навіть зруйнувати відносини між комунікантами, спричинивши несприятливі наслідки. Тому реалізація мовленнєвого акту відмови потребує певних стратегій. Через відмінності між різними мовами, культурами, життєвими звичками та етнічними способами мислення виникають розбіжності у способі здійснення відмови щуо реалізуються, зокрема, у китайській та японській лінгвокультурах. Щоб зменшити негативний вплив культурних відмінностей та інших факторів міжкультурної комунікації між китайцями та япониями, а також сприяти більш ефективній міжскультурній взаємодї, китайсько-японський мовленнєвий акт відмови слід ретельно проаналізувати як у теоретичному, так і в практичному аспекті. На даний момент вже є суттєві результати в зіставному дослідженні акту відмови, щуо здійснюється в китайській та японській лінгвокультурах. Ця стаття має на меті узагальнити та розглянути попередні дослідження, а також накреслити шляхи для подальшого інноваційного вивчення иієї проблематики.

Ключові слова: мовленнєвий акт відмови, міжкультурна комунікачія, культурні відмінності, стратегія відмови, зіставне дослідження.

\section{РЕЧЕВОЙ АКТ ОТКАЗА В КИТАЙСКОЙ И ЯПОНСКОЙ ЛИНГВОКУЛЬТУРАХ: СОВРЕМЕННЫЕ ТЕОРЕТИЧЕСКИЕ ПОДХОДЫ}

\section{Цзян Цинчуань, qingchuanjiang6@gmail.com}

\author{
аспирантка Учебно-научного института филологии \\ Киевский наџиональный университет имени Тараса Шевченко
}

\begin{abstract}
Отказ как речевой акт, который может угрожать обеим сторонам общения во время межкультурной коммуникации, является проблемой, требующей особого внимания. Если отказ будет осуществлен некорректно, это может не только повредить общению, но даже разрушить отношения между коммуникантами, повлекши неблагоприятные последствия. Поэтому реализачия речевого акта
\end{abstract}

(С) Цзян Цінчуань [Цзян Цинчуань], qingchuanjiang6@gmail.com Мовленнсвий акт відмови в китайській та японській лінгвокультурах: сучасні теоретичні підходи [Речевой акт отказа в китайской и японской лингвокультурах: современные теоретические подходы] (Англійською / На англ. яз.) 
отказа требует определенных стратегий. Из-за различий между разными языками, культурами, жизненныли привычками и этническими способами мылления возникают разногласия в способе осуществления отказа, которые реализуются, в частности, в китайской $и$ японской лингвокультурах. Чтобы уменьшить негативное влияние культурных различий и других факторов межкультурной коммуникации между китайцами и японцами, а также способствовать более эффективному межкультурному взаимодействию, китайско-японский речевой акт отказа следует тщательно проанализировать как в теоретическом, так и в практическом аспекте. На данный момент уже существуют результать в сопоставимом исследовании акта отказа, который осуществляется в китайской и японской лингвокультурах. Целью этой статьи является обобщение и рассмотрение предыдущиих исследований, а также начертить пути для дальнейшего инновачионного изучения этой проблематики.

Ключевые слова: речевой акт отказа, межкультурная коммуникация, культурнье различия, стратегия отказа, сопоставимое исследование.

\section{Introduction}

Refusal is "the act of directly or indirectly denying the other party's wishes when the communicator faces the four verbal acts of request, invitation, offer, and suggestion." Refusal behavior is a common phenomenon in various cultures, and its essence is a Face-Threatening Act (FTA). Refusal speech act is a kind of a speech act which might be qualified as likely to cause communication failure. That's why rejectors usually use a more polite refusal strategy for reducing the threat of interlocutor's face losing. Such scholars as Zhang Xiaoyin and Xiong Hongzhi mentioned in their paper that from the perspective of benefit, the beneficiary of the request is mostly the requester, while the beneficiary of the invitation might be both parties, and the beneficiary of offer and suggestion are often the recipients [Zhang Xiaoying, Xiong Hongzhi, 2017, p. 55]. Therefore, the refusal of the request usually places a greater burden on the other party and is more likely to hurt the other party's face. The refusal of the "request" is different from the refusal in other situations [Chen Fangze, Liu yu, 2009, p. 44]. Also the appearance of "requirements" heralded the emergence of "rejections". Therefore, the analysis of the speech act of refusal should start with the study of the speech act of "request" [Gao Yuyuan, 2018, p. 15]. In cross-cultural communication, the usage of appropriate refusal strategy requires not only the strong language skills, but also the linguistic awareness. In order to promote the success of cross-cultural communication and avoid cultural conflicts, it is necessary to conduct a comparative study on refusal speech act in different language and cultural backgrounds.

(C)Jiang Qingchuan [Czjan Cinchuan'], qingchuanjiang6@gmail.com Speech Act of Refusal in Chinese and Japanese Lingual Cultures: Contemporary Theoretical Approaches [Movlennjevyj akt vidmovy v kytajs'kij ta japons'kij lingvokul'turah: suchasni teoretychni pidhody] (in English) 
Due to different cultural backgrounds and ways of thinking, Chinese and Japanese adopt different refusal strategies. Therefore, it is easy to misunderstand when communicating across cultures. For example, Chinese tend in the beginning of communication to refuse the invitation or offer actually willing to accept it, because such communicative behavior is seen as expressing politeness in the Chinese culture. Such a behavior does not threat the other side's face, while in the Japanese cultural context it might threat. Thus, it is very important to understand the extralingual cultural circumstances of verbal ethnic communication. In daily communication, Japanese often avoid the direct ways of expressing their wishes and intentions, choosing an indirect or euphemistical speech acts. In 1976, Edward Hall pointed out that both Chinese and Japanese languages are languages providing the communicative needs of "high realm cultures", where senses and meanings are mainly determined by the cultural non-verbal context and cultural presuppositions [Zhang Yiwen, 2011, p. 143].

So no one can reach the expected pragmatic purpose if the communication context in Japanese communication is grasped incompletely, even including the facial expressions (which is often said “kuuki wo yo me/空気を読め” in Japanese). In addition, the "fuzzification" of language expression is also of typical character in the Japanese lingual culture. It means that some seemingly affirmative and positive response to the others' demands, actually imply a rejection. For instance, there is an investigation on the credibility of Japanese reply: "I'll think about it" (“kangaeteokimasu /考えておきます”) which demonstrated, that $70 \%$ of the Japanese believed that the utterance was not credible under condition that the social distance between the two sides of the dialogue is long [Duan Yanju, 2013, p. 98]. It is also relevant, when the two communicators are not very familiar with each other: an affirmative reply actually means a refusal.

Also scholars claimed that English-oriented politeness theory is not quite sufficient to explain a Japanese politeness.

\section{Previous research}

Liu Zhenquan mainly focused on "request" and "invitation" occasions, he discussed the similarities and differences in the expressions of rejection between Chinese and Japanese under different communicative circumstances. Fan Zheng and Yu Guiling discussed Japanese rejective expressions in different communicative genres [Fan Zheng, Yu Guiling, 2002, p. 94-98]. Xin Xiaona basing on Grice's cooperative principle and Leech \& Levinsion's politeness principle, fulfilled a study

(С) Цзян Цінчуань [Цзян Цинчуань], qingchuanjiang6@gmail.com Мовленнсвий акт відмови в китайській та японській лінгвокультурах: сучасні теоретичні підходи [Речевой акт отказа в китайской и японской лингвокультурах: современные теоретические подходы] (Англійською / На англ. яз.) 
on refusal strategies and their verbalizations in the context of different tactics of intimization taking into consideration the criterion of upper/lower status in Japanese language proficiency test. The purpose of this study is to analyze the relationship between the diversified verbalizations of Japanese refusal speech act and the effect of maintaining good interpersonal relationships [Xin Xiaona, 2006, p. 1-65]. Wang Jing studied the rejection strategy on the material of the Chinese and Japanese languages on the base of the "request-reject" conversation structure [Wang Jing, 2012, p. 71-77]. Cheng Xiaoping conducted a comparative analysis and categorization of the rejection expressions on the material of the Chinese and Japanese languages [Cheng Xiaoping, 2014, p. 27-28]. Qin Lang conducted a comparative study of the speech act of apologizing used by Chinese and Japanese college students [Qin Lang, 2015, p. 319-320]. Yuan Yijin made a comparative study of refusal speech act exercised by Chinese and Japanese based on the "upper and lower relationship" dimension [Yuan Yijin, 2016, p. 153-154]. Zhang Xiaohong, Xiong Hongzhi conducted a comparative study on the perspective of discourse politeness theory [Zhang Xiaohong, Xiong Hongzhi, 2017, p. 54-64]. Jing Huanru etc. explored the cultural psychology of Japanese refusal speech act [Jing Huanru, Wang Yongfa, Yang Qiuxiang, Wu Zheng, 2013, p. 174-175]. Chen Li analyzed the speech act of refusal from the pragmatic point of you [Chen Li, 2013, p. 223-225]. It was accentuated that Japanese often used "apologizing + reason", "gratitude + reason" and halfway stop sentence to reject.

Japanese scholar Moriyama gave a classification of Japanese refusals strategies, he summarized it into the following four types: straight type (iya kata) as the direct refusal; lie type (uso kata) like "today is not very convenient"; delay type (nobasu kata) as "I'll consider it"; prevarication type (gomakasi kata) like being silient with no reply or just giving smile [Moriyama, 1990, p. 59-66]. Yui researched the characteristics of Japanese refusal speech acts in foreigner's perspective, adopted methods of video and interview to order to collect language data and compared it with the previous studies [Yui, 1992, p. 266-227]. Fujimori pointed out, that in a close relationship Japanese commonly use the determination mode of "apologize excuse/reason - maintain relationship", but rarely use the semantic formula of "conclusion". However, in the Chinese communication it is quite different: the frequency of using the semantic formula of "conclusion" in order to express rejection has the highest index [Fujimori, 1994, p. 1-19]. Aramaki conducted the comparative research of refusal speech act within American and Japanese lingual cultures [Aramaki, 1999, p. 105-137]. Taketa did a case study about refusal behavior in

(C)Jiang Qingchuan [Czjan Cinchuan'], qingchuanjiang6@gmail.com Speech Act of Refusal in Chinese and Japanese Lingual Cultures: Contemporary Theoretical Approaches [Movlennjevyj akt vidmovy v kytajs'kij ta japons'kij lingvokul'turah: suchasni teoretychni pidhody] (in English) 
contact scenes [Taketa, 2000, p. 37-50]. Ito conducted a series of comparative studies of refusal speech act used in communication between Japanese and Malayans [Ito, 2002, p. 61-270, p. 179-2195, 2003, p. 49-59, p. 75-84, 2004, p. 1-16].

Generalizing the previous researches, it might be stated that: all studies show that the refusal speech act within the Chinese and the Japanese lingual cultures is significantly different.

In the Chinese culture, if the person which is about to get a rejection is in a higher status, he/she must be firstly respectively addressed (such as president, mayor, headmaster etc.). And the Chinese are likely to give the specific reasons when refusing the other person. Sometimes the "alternative plan" (such as giving the other a suggestion or an idea) often works as a polite refusal strategy. In addition, the Chinese are not inclined to reject the requests of their family members.

The Japanese have a higher frequency of regrets or apology for people with a higher status, and less for those with the lower status. The Japanese often apologize or express their regrets before refusing, and then open the reasons for it. The reasons for the Japanese refusal are not so specific as with the Chinese speaker's reasons: Japanese tend to give the obscure reasons. Japanese mainly adopt negative politeness strategies to avoid face threatening acts. It means that speakers would keep distance with each other to show respect and formality. Japanese culture is of "high realm", its information and meanings are mainly determined by the context (cultural background, etc.).

\section{Research status and prospects:}

Theory framework. In recent years, there appeared many researches on the specifics of refusal speech act. They are mostly based on J. Austin' speech act theory and Brown \& Levison's politeness theory. However, there are still a few studies on the comparison of the Chinese and the Japanese specific polite strategies from the perspective of Discourse Politeness (DP) theory, which was proposed by a Japanese linguist Usami Miyomi (宇佐美まゆみ) [Usami, 2001, p.9]. She regards conversation as a dynamic integral system and puts forward a theory of discourse politeness that transcends the level of single sentences and individual expressions focusing on the level of discourse analysis. The PD theory does not only consider the speaker, but also the receiver of a message, and advocates the objective grasp of politeness in dynamics.

Methodology. The previous researches mostly used the Discourse Completion Test (DCT) as the research method. This is a questionnaire on the phenomenon of

(С) Цзян Цінчуань [Цзян Цинчуань], qingchuanjiang6@gmail.com Мовленнсвий акт відмови в китайській та японській лінгвокультурах: сучасні теоретичні підходи [Речевой акт отказа в китайской и японской лингвокультурах: современные теоретические подходы] (Англійською / На англ. яз.) 
"refusal" speech acts designed according to the different given scenarios/situations. The analysis of language data is made basing on the answers provided in the questionnaire by the respondent. The corpus obtained in this way is represented mostly by single sentences. However, in actual conversation, refusal is often realized not just within a single sentence, not only in the frame of the model of "one question and one answer". Therefore, it is necessary to conduct a research within the paragraph or some units wider than it.

Corpus source. Corpus is usually collected with the help of DCT questionnaire, it also can arise from the literary works or TV series (these materials are derived from daily life, revolving the scenes of love, work, family, life etc. which are close to life and represent a natural dialogue). The research which uses corpus gives an opportunity not only to examine the entire conversation in combination with the context, but also provides a possibility to examine the speech act of refusal in a more comprehensive and deep mode according to the overall context background.

Perspective. In recent years there also appeared some studies made from the perspective of the impolite speech act. For example, Cheng Encai pointed out when comparing the rejection behavior within the Chinese and Japanese lingual cultures where "blaming" is one of the unique ways of rejection of the Chinese [Cheng Encai, 2011, p. 44]. On the other hand, some nonverbal acts of refusal, such as "shaking head", "waving hand", "being silent, not responding", "ignoring, just smiling or leaving", also need to be taken into consideration as paralingual elements which accompany the speech acts of refusal in different lingual cultures.

\section{Literature:}

1.陈访泽，刘玨. 日语书信中的拒绝策略及其语用功能---以针对请求的拒绝行为为

例 $[\mathrm{J}]$.广东外语外贸大学学报, 2009(6): 43-47.

2.成恩才. 中日拒绝邀请的行为比较研究---基于礼貌理论的视角 [D]. 西安外国语大 学, 2011: 44 .

3.陈丽. 日语拒绝言语行为的语用分析 $[\mathrm{J}]$. 大连民族学院学报, 2013（2）: 223225.

4.程晓萍. 论中日拒绝表达方式的异同 [J]. 文学语言学研究, 2014: 27-28.

5.段艳菊. 日语与拒绝行为与 “面子 (保全) 论” [J] . 出国与就业, 2013: 98.

6.范峥,于桂玲. 浅谈日语中的拒绝表现 $[\mathrm{J}]$ 。哈尔滨学报, 2002 (2): 94-98.

7. 高毓苑. 俄汉拒绝言语行为的语用对比研究[D].东北师范大学, 2018: 14.

(C) Jiang Qingchuan [Czjan Cinchuan'], qingchuanjiang6@gmail.com Speech Act of Refusal in Chinese and Japanese Lingual Cultures: Contemporary Theoretical Approaches [Movlennjevyj akt vidmovy v kytajs'kij ta japons'kij lingvokul'turah: suchasni teoretychni pidhody] 
8.敬焕茹，王永发，杨秋香，吴征. 日语拒绝言语中的文化心理 $[\mathrm{J}]$.边疆经济与文 化, 2013 (7) : 174-175.

9.刘振泉. 日本语言文化论集 [ M ].北京:北京大学出版社, 1998.

10. 王静. 汉日拒绝策略理论与实证对比研究---以“请求-拒绝”会话结构为研究中心

[J]. 日语学习与研究, 2012: 71-77.

11. 秦朗. 中日大学生道歉言语行为的对比研究 $[\mathrm{J}]$. 理论探讨, $2015: 319$.

12. 辛晓娜. 日语能力考试中拒绝行为的语用考察---以拒绝策略和拒绝结构为研究中

心[D]. 广东外语外贸大学, 2006: 1-65.

13. 苑艺瑾. 跨文化交际视角下汉日拒绝表达言语行为的对比研究---基于 “上下” 关

系的维度 $[\mathrm{J}]$. 汉语研究, 2016: 153 .

14.赵刚, 贾琦. 间接言语行为的日汉对比研究 [J]. 旧语研究, 2004 (2): 67.

15.张㴋尹, 熊红芝. 话语礼貌理论视角下的中日 “请求---决绝” 行为对比研究 $[\mathrm{J}]$

. 浙江外国语学院学报, 2017 (1) : 55-64.

16. 张奕雯. 解读沉默在高语境文化和低语境文化中的不同用途 $[\mathrm{J}]$. 英语教学, 2009 : 42-47.

17.森山卓郎. 拒绝策略---人际关系调查与沟通 [J].语言, 1990: 59-66.

18. 熊井浩子. 外国人待遇行为分析 (2) ---以拒绝行为为中心 $[\mathrm{J}]$. 静冈大学文科

研究报告人文社会科学（28卷），静冈大学文科系，1992：266-227.

19. 藤森弘子. 日本学者视角下的语用转移---以 “拒绝” 为例 $[\mathrm{J}]$. 日本语学: 日本语 教育论集, 1994: 1 .

20. 荒卷朋子. 美国人和日本人的拒绝行为的比较 $[\mathrm{J}]$. 长崎大学留学生中心纪要, 第7号， 1999: 105-137.

21.武田加奈子. 接触场景中拒绝行为的案例研究 $[\mathrm{J}]$. 日本语学论说资料, 2000 : 37-5.

22. 伊藤恵美子. 马来语母语者的语用能力与在日本生活时间的关系：“拒绝” 邀请 行为中的工程系本土的礼貌 $[\mathrm{J}]$. 日本语教育, $2002 \mathrm{a} （ 115 ） ： 61-70$.

23.伊藤恵美子. 马来语母语者中间语言的语用特征 : 拒绝的普通性和特殊性 $[\mathrm{J}]$. 语言的科学, 2002 b (15) : 179-195.

24.伊藤恵美子. 为什么马来语母语人不拒绝: 基于问卷调查和后续访谈分析 $[\mathrm{J}]$.

(С) Цзян Цінчуань [Цзян Цинчуань], qingchuanjiang6@gmail.com Мовленнсвий акт відмови в китайській та японській лінгвокультурах: сучасні теоретичні підходи 
语言和人类, $2003 \mathrm{a}$ (4) : 49-59.

25.伊藤恵美子. 拒绝要求的选择：“默里困境” 的验证 $[\mathrm{J}]$. 语言文化学会论集, 2003b (21) : 75-84.

26.伊藤恵美子. 马来语母语者拒绝言语行为的语用特征 : 主要考虑对请求的回应

[C]．库克罗斯：国际交流论集, 2004b（1）：1-16.

27. 伊藤恵美子. 在拒绝场景中识别的爪哇语/印度尼西亚语表达 : 基于霍夫斯泰德的 标准解释 $[\mathrm{J}]$ 。东亚语言研究, 2004c（7）：19-29.

28. 宇佐美麻由美. 话语的礼貌：礼貌的话语理论概念 $[\mathrm{J}]$. 第七回国立国语研究所 国际研讨会报告书，2001: 9-58.

\section{References:}

1. Chen Fangze, Liu Jue. «Refusal Strategies and Their Pragmatic Functions in Japanese Letters--- A Case Study of Refusal to Requests [J].» Journal of Guangdong University of Foreign Studies, 2009 (6): 43-47.

2. Cheng Encai. «A Comparative Study between Japan and China on the Act of Refusing Invitations--- from the Perspective of Politeness Theory [D].» Xi'an International Studies University (2011): 44.

3. Chen Li. «A Pragmatic Analysis of Japanese Refusal Speech Acts [J].» Journal of Dalian University for Nationalities 2 (2013): 223-225.

4. Cheng Xiaoping. «On the Similarities and Differences of Chinese and Japanese Refusal Expressions [J].» Literary Linguistics Research (2014): 27-28.

5. Duan Yanju. «Japanese Language and Refusal Act and "Face (Saving) Theory" [J].» Going Abroad and Employment (2013): 98.

6. Fan Zheng, Yu Guiling. «On the Expression of Refusal in Japanese [J].» Harbin Journal 2 (2002): 94-98.

7. Gao Yuyuan. «A Pragmatic Comparative Study of Refusal Speech Acts between Russian and Chinese [D].» Northeast Normal University (2018): 14.

8. Jing Huanru, Wang Yongfa, Yang Qiuxiang, Wu Zheng. «Cultural Psychology in Japanese Refusal Speech [J].» Frontier Economy and Culture 7 (2013): 174-175.

9. Liu Zhenquan. Anthology of Japanese Language and Culture [M] (Beijing: Peking University Press, 1998).

10. Wang Jing. «A Comparative Study of Chinese and Japanese Refusal Strategy Theory and Empirical Research---Focusing on "Request-Refusal" Conversational Structure [J].» Japanese Learning and Research (2012): 71-77.

11. Qin Lang. "A Comparative Study of Chinese and Japanese College Students' Apology Speech Act [J].» Theoretical Discussion (2015): 319.

12. Xin Xiaona. «Pragmatic Consideration of Refusal in the Japanese Language Proficiency Test--- Focusing on Refusal Strategies and Refusal Structures [D].» Guangdong University

(C) Jiang Qingchuan [Czjan Cinchuan'], qingchuanjiang6@gmail.com 
of Foreign Studies (2006): 1-65.

13. Yuan Yijin. "A Comparative Study of Chinese and Japanese Refusal to Express Speech Acts from the Perspective of Cross-cultural Communication: Based on the Dimension of "Up and Down" Relationship [J].» Chinese Studies (2016): 153.

14. Zhao Gang, Jia Qi. «A Japanese-Chinese Comparative Study of Indirect Speech Acts [J].» Old Language Research 2 (2004): 67.

15. Zhang Xiaoyin, Xiong Hongzhi. "A Comparative Study of Chinese and Japanese "Request-Refusal" Act from the Perspective of Discourse Politeness Theory [J].» Journal of Zhejiang University of Foreign Languages 1 (2017): 55-64.

16. Zhang Yiwen. «Interpretation of the Different Uses of Silence in High-context Culture and Low-context Culture [J].» English Teaching (2009): 42-47.

17. Takuro Moriyama. «Strategy for Refusal--- Interpersonal Relationship Survey and Communication [J].» Language (1990): 59-66.

18. Hiroko Kumai. "Analysis of Treatment Behaviors of Foreigners (2)--- Focusing on Refusal Behavior [J].» Shizuoka University Liberal Arts Department Research Report Humanities and Social Sciences 28 (Shizuoka University Liberal Arts Department, 1992): 266-227.

19. Hiroko Fujimori. «Pragmatic Transfer from the Perspective of Japanese Scholars--- In the Case of "Refusal" [J].» Japanese Studies / Japanese Education Theory (1994): 1.

20. Tomoko Aramaki. «Comparison of Americans and Japanese Refusals [J].» Bulletin of Nagasaki University International Student Center 7 (1999): 105-137.

21. Kanako Takeda. «Case Study on Refusal acts in Contact Scenes [J].» Japanese Academic Editorial Material (2000): 37-45.

22. Emiko Ito. «Relationship between Malay Native Speaker's Pragmatic Ability and Staying in Japan: Politeness of Engineering Bumiputera in the Act of " Refusal " to solicitation [J].» Japanese Language Education 115 a (2002 a): 61-70.

23. Emiko Ito. «Pragmatic Features Found in the Intermediate Language of Malay Native Speakers: Normality and Peculiarity in Disclaimer [J].» Science of Words 15, 2002 b: 179195.

24. Emiko Ito. «Why Don't Malay Native Speakers Refuse: Analyzing from Questionnaire Surveys and Follow-up Interviews [J].» Words and Humans 4 (2003 a): 49-59.

25. Emiko Ito. "On the Choice of Refusal to Solicitation: Verification of the" Murray Dilemma " [J].» The Society of Language and Culture 21 (2003 b): 75-84.

26. Emiko Ito. «Pragmatic Characteristics of Malay Native Speakers' Refusal Expressions: Mainly Considering Responses to Requests [C].» Kukros: International Communication 1 (2004 b): 1-16.

27. Emiko Ito. «Javanese / Indonesian Expressions Recognized in the Refusal Scene: Interpreted from Hofstede's Index [J].» Language Studies in East Asia 7 (2004 c): 19-29.

28. Mayumi Usami. «Politeness of Discourse: Politeness's Discourse Theory Concept [J].» Report of the 7th National Institute for Japanese Language and Linguistics International Symposium (2001): 9-58.

(С) Цзян Цінчуань [Цзян Цинчуань], qingchuanjiang6@gmail.com Мовленнєвий акт відмови в китайській та японській лінгвокультурах: сучасні теоретичні підходи [Речевой акт отказа в китайской и японской лингвокультурах: современные теоретические подходы] (Англійською / На англ. яз.) 